\title{
Green Hospital Design: Integrating Quality Function Deployment and
}

\section{End-user Demands}

\begin{abstract}
There is a rapidly growing awareness amongst the public of facilities where the design incorporates green construction principles. This paper aims to study the quality function deployment (QFD) concept and technique when implemented in the construction industry with a particular focus on supporting green hospital design by identifying the end-user factors (concerns) that affect the design. This research develops QFD tools for green hospital designs known as the house of quality green design (HOQGD). Data were collected using a questionnaire survey distributed to public and private hospital end-users in Klang Valley, Malaysia. Findings revealed that end-users perceived "safety mechanisms during emergency" as being of the utmost importance and also the feature they were most satisfied with. The other demanded qualities were at an average degree of satisfaction; however, the end-users considered that green hospital design must make efforts to maximize the use of natural light and ventilation while considering the building orientation; materials should be free from toxicity and be environmentally friendly; the landscape should be strategically designed and the facilities should increase the sense of a healing environment, and water efficient equipment should be installed. Accordingly, these were prioritized and incorporated in the developed HOQGD to inform green hospital design for both public and private facilities.
\end{abstract}

Keywords: Quality Function Deployment (QFD), green civil engineering, green hospital design, House of Quality Green Design (HOQGD), customer satisfaction

\section{Highlights:}

1. We survey end-users of hospitals regarding perceptions of green design elements

2. Quality Function Deployment (QFD) is used to develop technical specifications

3. A House of Quality Green Design prioritizes specifications for future projects

4. Analysis shows less satisfaction with sustainability factors than safety features

5. Authorities should ensure implementation of sustainable specifications 


\section{INTRODUCTION}

Among the many studies on green design and construction, little attention has been paid to the systemic incorporation of end-user demands. It is recognized that sustainability and green building commitment improves financial performance, competitive positioning, and market differentiation and is therefore emerging as an important competitive tool for construction companies (Han and Shin, 2014). However, little research has been conducted on how hospitals' end-users - both the staff that work there and the visiting public - perceive green hospital designs. While financial and competitive positioning for construction firms is important, care must also be taken to ensure the long-term success of such projects by ensuring that other, less tangible, success factors are also considered; this can be accomplished by examining and incorporating user perceptions into the final design. Green building principles are redefining and revolutionizing building practices and are emerging as a response to growing societal concern over pollution and environmental damage, increasing awareness and acceptance of climate change, decreasing natural resources, increasing energy cost, and increasing demand for sustainability in building design and construction (Aliagha et al., 2013).

Green rating tools for evaluating and measuring the environmental performance of a building have been gaining global popularity. Consequently, a plethora of green rating systems with different rating criteria have emerged with the commonly applied systems including the US Leadership in Energy and Environmental Design (LEED), the UK Building Research Establishment Environmental Assessment Method (BREEAM), Singapore’s BCA Green Mark, and Australia’s NABERS rating system. The Malaysian rating system, the Green Building Index (GBI), was developed jointly by the Association of Consulting Engineers Malaysia (ACEM) and the Malaysian Institute of Architects. The objective of GBI is to save energy and resources, recycle materials, and adapt buildings to the Malaysia climate, culture, and environment. Such contemporary approaches encourage environmentally responsible and 
resource-efficient decisions by accounting for requirements throughout a building's life-cycle; i.e., considering the entire cycle from design through to construction, operation, maintenance, renovation, and demolition (Liu and London, 2013). In recent years, there has been an emerging subset of green design that has been revolutionizing hospital design by employing sustainable technologies, energy saving systems, and recyclable or renewable resources and materials (Gudiene et al., 2013). Green hospital design aspires to provide users with energy savings and a comfortable environment through innovative designs and green techniques. With many green design elements already specified during the design phase and coming from external sources (e.g., funding agencies), the overall perception of the facility's users must also be accounted for; the impact of green design on the users of the facilities has been under-researched.

This research is important, as while many building design elements might contribute to the reduced operating expenses of the facility (McGraw-Hill Construction, 2008), we have less awareness of the relative importance of each to facilities end-users. The application of life-cycle analysis (LCA) or lifecycle costing has enabled evaluation of costs (Woodward, 1997; Wübbenhorst, 1986), energy use (Ramesh et al., 2010), or other environmental impact factors (an overview is provided by Ortiz et al. (2009)). In contrast to LCA, our focus is not on the analysis of costs or environmental impact, but rather the perceptions of the end-users regarding the sustainability initiatives embodied in the project, so that these can inform the technical specifications of future projects to meet user requirements. Within hospitals and healthcare facilities, the impact of the environment on users is more important than in offices or other commercial environments, because of the intention to create a place of healing and recovery (Gross et al., 1998). Therefore, we require a greater understanding of end-user concerns relating to design elements in green hospitals as this provides an important input into future green hospital design processes. 
This paper aims to identify the factors that can affect the end-users' perception of quality of green hospital design, rather than a life-cycle analysis of the environmental impact. We address the need for, and inclusion of, the end-user preferences into the design principles through the use of quality function deployment (QFD). In doing this, the contribution of this paper is an analysis of the end-user preferences in green hospital design and how these are prioritized and incorporated into the existing green-design based literature. Given that QFD is a well-applied technique in product design (Zaim et al., 2014; Moldovan, 2014), this study uses QFD to identify the factors (customer concerns) that affect the quality of green hospital design and to develop a QFD tool that will inform future green hospital designs (HOQGD). This paper determines the suitability and practicability the concept and application of QFD in green construction and also connects this with factors that may help broaden the application of the model into different settings. By identifying relevant criteria and characteristics of green hospital design, the HOQGD model is developed to emphasize and support green design and provide integration of customer preferences, knowledge, and information. Using the HOQGD platform, design experts can design and construct green buildings based on the green design-related information that is integrated and analyzed in the HOQGD.

The next section provides an overview of the green design principles and key considerations, followed by an overview of QFD. This provides background on crucial elements that will need to be considered and how the research instruments were derived from the literature. Section three addresses the methodology and the research sample. Section four presents the results in relation to both public and private hospitals. Section five discusses application of the QFD design principles in hospital design. The final section summarizes the article and discusses the implications of these results.

\section{QUALITY FUNCTION DEPLOYMENT (QFD) AND GREEN BUILDING DESIGN}


As green design becomes increasingly important in the marketplace it will become embedded in design processes. While there is a long history in product design of including a range of different preferences during the design process, less has been done to include green design preferences in construction. QFD is a key tool that may support this inclusion of green principles in construction.

\subsection{Green building design}

While there are many green design principles, the core concepts often focus on the production and use of energy, water resources, the use of solar energy to improve electricity generation and reduce use of electricity, improved aeration, climatic features, and the long-term impact building materials the consideration of the life-cycle of the facility. Green building techniques were developed during the world's energy crisis in 1970’s and have been used since (Mao et al., 2011). There is wide recognition that green design can bring financial benefits during both the construction and operational phases. Green building strategies reduce buildings’ operating costs by 8-9 percent, increase building value by 7.5 percent, realize a 6.6 percent return on investment, increase occupancy ratio by 3.5 percent, and increase rent ratios by 3 percent (McGraw-Hill Construction, 2008).

The Construction Industry Development Board of Malaysia (CIDB), which monitors national construction activities, found that environmental and other sustainability issues were among the top issues facing the construction industry (Construction Industry Development Board, 2000). While it is vital for green buildings to provide a satisfying environment, they must also achieve economic efficiency by minimizing redesign and rework. Economic efficiency can be ensured through evaluation of inputs into the construction industry, including labor (Abdul-Rahman et al., 2012), and by managing the design process carefully. In addition to receiving greater support from stakeholders, the ongoing impact of green design should be reflected through reduced operating expenses; e.g., the Malaysian 
Health Minister noted that public hospitals would turn to green technology to reduce their electricity bills (Morden, 2011).

Integration of green design into healthcare buildings must meet rigidly defined quality levels to ensure that patients are comfortable and are treated with appropriate care. Green design emphasizes a number of features (Fik, 2005; Huff, 2009): reducing energy use; improving aeration; using passive solar heating and cooling; considering the life-cycle impact of building materials; improving water-use, capture, and -recycling; and the integration of climatic- and site-features (Ismail, 2013).

Reducing energy use is a key focus for green designers, especially when considering ventilation and lighting. Maximizing the use of natural lighting during the day can reduce energy costs and improve the atmosphere for buildings' users. The importance of access to natural light and the impact this has on buildings’ users has been established, including the way it can significantly change behaviors; e.g., use of natural lighting improves sales volume at retail outlets versus artificial light (Heschong et al., 2002). Green design facilitates an integrated choice of building function and orientation; e.g., through combinations of high insulation levels; capturing heat and energy from geothermal or other natural resources; use of renewable energy installations (e.g., photovoltaic cells, wind turbines, or solar water heating); careful harvesting of daylight; use of shading tools appropriately during the day; or optimizing building occupancy through smart sensors (Davidson, 2013).

Improving aeration in all occupied areas in facilities and striving to attain high air quality through effective construction protocols and designs (e.g., to remove dust, airborne toxins, and other materials) and through material specifications (e.g., requiring materials to contain no undesired chemical substances or compounds that may be hazardous). 
Passive solar heating and cooling is supported by site design to select and use a site that maximizes passive solar heating and cooling opportunities. The site must conserve natural resources (e.g. trees and wildlife habitats) and minimize land interference and erosion.

Considering life-cycle impact of building materials reduces the environmental impact of the materials and products employed across the life-cycle of the facility; priority is given to resources with smaller impact on the environment and energy usage. This focus on the life-cycle begins as early as the extraction or manufacture of the materials or products to be used. The final materials must be nontoxic, have additional features, be easily saved and recycled at the end of a buildings life-span, and reduce costs for activities undertaken by building services providers.

Improving water-use is achieved through various mechanisms of green design focused on efficient water use; e.g., rainwater harvesting, use of fixtures that conserve water, waste water treatment and recycling, green roofing, and control of storm water release. For example, harvesting rainwater requires designs that raise the $\mathrm{pH}$ of collected water and the final treatment and elimination of waste water. This reduces the burden on municipal infrastructure to supply clean water. Hospital systems often operate for decades and therefore require well-constructed and efficient systems.

Integration of climatic- and site-features ensures that a green structure must not only be sustainable itself but it must also ensure the design integrates important elements of sites' climatic conditions. Fundamental elements integrated into green design are the site's geology, hydrology, ecosystem, regional climate, and the specific micro-climates. Such considerations yield increases in user comfort levels and decreases in both energy consumption and operating cost. Both location and design should encourage sustainable and healthy transport options (e.g., use of mass transit, cycling, or walking). 


\subsection{Quality function deployment (QFD)}

The QFD concept and design approach was introduced by Professor Akao in 1966 as a customerdriven product development tool to improve design by translating customer needs and requirements into design requirements (Kamvysi et al., 2014). The translation process involves the identification and quantification of customer desires (e.g., relating to ease of writing with a pen) into measures that designers and engineers are able to use (e.g., the ink viscosity and pressure the tip of the pen) for each stage of the product development (Rosenthal, 1992). A key outcome is the increase of customer satisfaction with the features incorporated (Akao, 1990; Gudiene et al., 2013). QFD has four phases: product planning, product design, process planning, and process control. Each phase, or matrix, represents a more specific aspect of the requirements. Relationships between elements are evaluated for each phase. Each translation uses a matrix, called the house of quality (HOQ). The HOQ identifies the customer requirements and then establishes the priorities for design requirements (Hauser \& Clausing, 1988). Only the most important aspects from each phase are deployed into the next matrix. While QFD has been used for more than 40 years, it has been predominantly applied within the manufacturing industry (Karsak \& Dursun, 2014).

With continuing emphasis on quality in the construction industry, QFD can make a difference between success and failure in an increasingly competitive environment (Haron et al., 2015). The appropriate implementation of QFD can improve engineering knowledge, productivity, and quality while simultaneously reducing costs, product development time, and engineering changes (Stevenson, 2007; Raharjo et al., 2008).

\subsection{QFD in green building design}


The most challenging phases in a green building life-cycle are the construction phase and the design phase. Problems occurring at the construction phase require significant efforts to correct without causing undue environmental damage. On the contrary, consideration of variables at the design phase allows earlier identification of problems in projects. Identifying and rectifying problems earlier reduces the need for later re-work during construction, ensuring higher levels end-user satisfaction as there are fewer construction defects on completion of the project (Abdul-Rahman et al., 2014). Thus, the use of QFD during the design phase can significantly minimize problems during or after construction, representing a significant return on the investment from using QFD. Builders that emphasize quality and the perception of quality in green construction can create an advantage over competitors in the globalized market. QFD allows builders to continually improve their systems and focuses attention on how they can discover, create, increase, and deliver more value. A building mechanism that measures customer satisfaction through QFD quality charts may become a necessary pre-requisite for competitive construction firms in the future.

Given these advantages, QFD has been applied in the construction industry (Gargione, 1999) in a range of ways (Low, 2001). It has primarily been used as a tool that gives priority to crucial elements, allowing construction to reflect the needs of the customer; e.g., to improve facility layout and specifications in healthcare projects (Dijkstra and van der Bij, 2002; Lim and Tang, 2000). For this reason, interest in QFD has risen in construction industry as firms race to become more competitive (Mc Lellan, 1994). Similarly, QFD for green design is an innovative design tool for developing environmentally friendly products, using Fuzzy Multi-Attribute Utility Theory to provide superior cost estimation ability early in the design phases of development (Dong et al., 2003). Application in the construction industry has been slow, with the most significant integration of fuzzy set theory and QFD aiming to develop an evaluation model to optimize green construction alternatives using function-cost 
analysis (Shi \& Xie, 2009). Thus, while QFD is widely adopted in product development, we have not seen similar advances in the use of QFD in construction management, nor in hospital design.

\subsection{House of quality (HOQ)}

Each translation (e.g., from customer requirements into product characteristics) when using QFD uses a matrix known as the house of quality (HOQ). The HOQ identifies the customer requirements and then establishes the priorities for design requirements (Hauser \& Clausing, 1988). HOQ is represented in a diagram (that visually looks like a house) that defines the relationship between customer demands and the requirements placed on the product attributes (Hauser, 1993).

At present, the construction industry is rapidly moving towards a strong environmental agenda, forcing the adoption of new quality approaches. As a result, there is more pressure on construction managers to be mindful of the environmental impact of their work (Ibrahim et al., 2010). Morden (2011) reported that the Malaysian government has announced that the public hospitals are 'going green'; this indicates that in Malaysia, green hospital design is still in its infancy. Therefore, there is a significant opportunity to better understand customer requirements and the design elements using design approaches such as QFD. Used in this way, QFD can become a crucial aid to the construction industry during the development of capabilities that will allow construction firms to meet green construction targets.

\subsubsection{Developing a house of quality model for green design}

Quality charts are foundational in HOQ and require two main elements: a set of Demand Qualities (or customer requirements) and a set of Quality Elements (or technical requirements) (Ng, 1999). A Demanded Quality Deployment Chart, generally called a quality chart, consists of feedback about the 
demanded quality users require in products or services. These requirements are often ill-defined from a technical perspective and must be translated or converted into well-defined quality elements that are meaningful for engineers and designers. The quality characteristic deployment chart consists of design elements that are used to evaluate the quality. Each quality element is assessed as being either of primary, secondary, or tertiary importance and are grouped hierarchically. Each element is classified by the degree of importance and how it affects other elements; thus, details of each element become measurable quality characteristics used as inputs in the next chart.

In the case of green hospital design, the customers' input becomes the customer requirements or the Demand Qualities. To comply with customers’ demands, a matrix is developed that incorporates all relationships and allows these to be evaluated. Each column is ranked based on the calculated total score at the bottom. The item with the highest score becomes the first consideration for further improvement.

\subsubsection{Quality demands}

Customer satisfaction is of utmost importance in all organizations as customer satisfaction with output drives and determines organizational success. The desires or concerns of the customer are therefore a crucial input for any business that plans to produce the right product or service (Guinta \& Praizler, 1993). For example, “WHAT” does a hospital patient want besides treatment? Most likely, patients also desire a pleasant, restful, and spacious area where they are able to relax, as this helps them to recover. From the designer’s perspective, customers’ needs may seem vague, qualitative, incomplete, and sometimes inconsistent. Customers only express what they want and this is usually not easily quantifiable and it may therefore make little sense to designers; e.g., the customer simply says "it must be comfortable”. Therefore, the designer's responsibility is to convert these data into more precise 
specifications and then classify specifications as either primary, secondary, or tertiary customer demand. Finally, prioritization of quality demands based on customer feedback helps designers to figure out how these customer desires can be satisfied by a product/service. Designers need detailed, technical-oriented requirements (e.g., indicating how to meet the customers' demands) for the design.

Table 1 presents a list of the customer demanded qualities that should be integrated in green hospital design. Six categories of green design elements are included: energy efficiency, indoor environmental quality, sustainable site planning and management, materials and resources, water efficiency, and innovation. These match the six categories established by GBI and so this small and manageable number of primary categories provided by GBI were used to inform the design of the study; the secondlevel categories, of detailed and specific elements, were derived from the literature (Fik, 2005; Huff, 2009; Ismail, 2013) and clustered under the first-level categories from the GBI.

\subsubsection{Quality elements}

A specific quality element is the technical characteristic that represents the "HOW" the organization will attain the demanded quality "WHAT"s. These quality elements consist of design characteristics, processes, facilities, and methods to fulfil the given demanded qualities. It is important that different ideas and perspectives are obtained from every discipline or department involved in the construction and use of the hospital, to ensure the data are representative and multidisciplinary (Guinta \& Praizler, 1993). Table 2 provides a list of the quality elements identified for the green hospital design, drawing from the reviewed literature (Fik, 2005; Huff, 2009; Ismail, 2013). The quality elements relate to aspects of design, environmental condition, and authority (i.e., relating to the specifications and subsequent control and enforcement of design decisions). 


\section{RESEARCH METHODS AND PROCEDURES}

This research aims to identify the factors that can affect the quality of green hospital design. This is the essence of QFD, seeking and using customers’ feedback based on their experience and need. The research methodology consisted of a questionnaire survey (informed by literature), which was distributed to a targeted group of randomly selected respondents. This investigation focused on three groups of respondents (medical staff, hospital staff, and patients and visitors) in private and public hospitals. Statistical analysis of the data collected determined the factors that could affect a green hospital design and these informed the development of the HOQGD.

Meeting customers' needs is crucial when it comes to selling products or services. In green hospital design, medical staff, workers, and patients and visitors are the targeted customers or end-users of the hospital. To improve understanding about the needs and concerns of the hospital end-users, a questionnaire survey was formulated to ascertain the perceived importance of 18 demand quality factors over six categories (as discussed in §2.4.2). The categories surveyed included energy efficiency, indoor environmental quality, sustainable site planning and management, materials and resources, water efficiency, and innovation (as outlined in Table 1). Based on recommendations in Salant and Dillman (1994) and guidelines for writing survey questions (e.g., Dillman, 2000, 2007; Mitra \& Lankford, 1999; Salant \& Dillman, 1994; Tourangeau, Rips, \& Rasinski, 2000), the questionnaire survey was developed to motivate respondents to deliver complete and accurate information. The quality demand factors were derived from the GBI categories and the second-level categories were based on relevant literature (Fik, 2005; Huff, 2009; Ismail, 2013), and past research provided the foundation for the design of the preliminary questionnaire. 
A pilot study was conducted, testing the preliminary questionnaire using face-to-face interviews with two medical academics and three random hospital staff and visitors. This ensured the questions were clear, unambiguousness, and comprehensible in layman terms. The feedback received was used to improve the quality of the questionnaire and improve respondent comprehension, ensuring data validity.

The final questionnaire was structured into two sections. Section A consisted of questions about the respondents’ demographics and background details (e.g., gender, age, position in hospital, level of education, and frequency of visits to the hospital). Section B evaluated the degree of importance and degree of satisfaction of each of the six factors (Table 1) that can impact the perception of quality of a green hospital design. Table 2 represents a list of quality elements identified for the green hospital design

Table 1 inserts here

Table 2 inserts here

100 questionnaires were distributed at three public hospitals and a further 100 questionnaires at three private hospitals in Klang Valley, Malaysia. A total of 149 responses were received; an overall response rate of 74.5\%. 86 responses were received from the public hospitals users (86\%) and 63 private hospital end-users participated (63\%). Statistical analysis was conducted using Statistical Package for Social Sciences (SPSS 19.0) software. The questionnaire's internal reliability of the factors was tested, giving a Cronbach coefficient of 0.875 , which was judged to be acceptable (Nunnally 1978, p. 245), and indicates that the questions relating to quality demands and quality elements were internally consistent; therefore, the factors were included in the analysis. 
To analyze the differences in factors affecting the perception of green hospital design quality, both private and public hospital data were combined. The Kruskal-Wallis test was used as a suitable, nonparametric alternative to the ANOVA that can be used to test ordinal data (Conover, 1999). We used the Kruskal-Wallis test to determine whether there were any statistically significant differences between the distributions of three or more independent (unrelated) groups; specifically, whether there were differences between the groups in terms of how they perceived the importance of the factors in the survey. Pairwise comparisons were performed using Dunn's (1964) procedure with a Bonferroni correction for multiple comparisons. Where there were no differences in the importance score between the groups, no results are reported. (Post-hoc analysis revealed the statistically significant differences reported in Table 5 to Table 11.)

To determine the differences between two groups using ordinal dependent variables, the MannWhitney U test (also known as the Wilcoxon-Mann-Whitney test) was used. This is a suitable nonparametric alternative to the independent samples t-test (Dinneen \& Blakesley, 1973), using an exact sampling distribution for $U$ (Dinneen \& Blakesley, 1973) in the factors of education level (data were re-coded as either having attended college/university or not) and gender.

\section{RESULTS AND FINDINGS}

The survey results have been analyzed to develop an understanding of customer demands on green hospital design and then they were used to construct the HOQ for hospital design. The findings are presented after being analyzed for each of the public and private hospitals. For each type of hospital, the background of respondents and their evaluation of the importance of the factors and satisfaction on the hospital based on the quality demanded are described. Linear regression and Mann-Whitney $\mathrm{U}$ test were used to discover the associations of the dependent variables (demanded qualities) to the 
independent variables (gender, age, position in hospital, level of education, and frequency of visits to the hospital). The following discussions are provided where there are statistically significant associations (i.e., where the p-values $<0.05$ ). This section concludes with the development of the HOQGD for public and private hospitals.

\subsection{Public and private hospitals}

From the public hospitals sample, 86 responses to the questionnaire were received, a response rate consisting of $41.9 \%$ visitors, $26.7 \%$ medical staff, $22.1 \%$ patients, and $9.3 \%$ hospital workers (Table 3). Most respondents were female (64\%) and had a tertiary qualification (72.1\%). The reason for the high percentage of respondents with tertiary qualification is probably because all the studied hospitals are located in Klang Valley, which is the most developed region in this country, thus we expect most of the medical staff, patients, and visitors to have a better educational background than if the research had been conducted in other regions of Malaysia. Klang Valley (also known as the Kuala Lumpur Metropolitan area or the Greater Kuala Lumpur area) is an area in Malaysia which is centered on the capital city Kuala Lumpur and includes its adjoining cities and towns in the state of Selangor. 46.5\% of respondents are from the age of 21 to 29 and $30.2 \%$ are between the age of 30 and 40 . The remaining respondents were above 40 or below 21 years old. Daily visits to the hospital were reported by 33.7\% of respondents.

Table 3 summarizes 63 respondents from the private hospitals sampled with the questionnaire survey, consisting of $36.5 \%$ patients and $36.5 \%$ visitors, $20.6 \%$ medical staff, and $6.3 \%$ hospital workers. Respondents consisted of 40 women (63.5\%) and 23 men (36.5\%). 73.0\% of respondents had been educated at the tertiary level while and the remainder (27.0\%) had secondary education. The highest percentage of participants (57.1\%) belonged to the age group of 21 to 29 years' of age, and the lowest 
percentage of participants (4.8\%) were more than 40 years old. $23.8 \%$ of the respondents noted they visited the hospital daily, while the rest of participants (76.2\%) reported fewer visits to the hospital.

Table 3 inserts here

The respondents were asked to evaluate a series of factors that may affect their perception of the quality of a green hospital design on the scale 1 to 5 (where 5 indicated that the factor was very important).The average evaluation for each factor is presented in Table 4 for public and private hospitals; these data indicate that safety-related factors are the most highly regarded factor in both types of hospitals. The factors of maximizing natural light and limiting the disruption from storm water were rated as the least important in the public and private hospitals, respectively. Based on the scale 1 to 5 , the average of importance for each factor as rated by the respondents is presented in Table 4 .

Table 4 inserts here

\subsection{Impact of age}

The different age groups tended to report few differences in how they evaluated the importance of the factors (Table 5). Most notably, young adults (ages 21-40) rated the safety considerations for occupants and users as being of high importance. The healing nature of the environment was considered to be more important amongst the older users than the young users (under the age of 20).

Table 5 inserts here

\subsection{Impact of position in the hospital on importance of factors}


The results indicate that visitors, medical staff, and patients tend to have slightly higher expectations regarding the importance of the factors than hospital workers do. These factors seem to relate to how pleasant it will be to work in that particular hospital environment. Visitors tended to rate these factors lower than hospital staff and medical staff. Patients place importance on the building orientation and the strategic landscape. Medical staff are more discerning regarding the nature of the healing environment, building orientation, and natural ventilation; these factors may also correlate with the belief that patients recover more quickly under these ideal environmental circumstances.

Table 6 inserts here

\subsection{Impact of frequency of visits to the hospital}

These factors relate to how pleasant it will be to spend time in the hospital environment (Table 7). People that are in the environment every day clearly want a pleasing environment, more so than those that spend less time in that environment. Users that are in the hospital daily have a more strongly held belief that a healing environment is important and that the facilities should be safe for occupants and users.

Table 7 inserts here

\subsection{Impact of education level}

The amount of education a hospital user has plays a role in how they evaluate the factors (Table 8). In all cases, people with a higher level of education tended to rate the factors of building orientation, 
healing environment, safety for occupants and users, and appearance as being more important than those with a high-school level of education. Interestingly, these factors tend to relate to the environmental aesthetics, indicating that those with higher education are more discerning in their evaluation of the aesthetic qualities of the environment and have a stronger appreciation for the facility safety.

Table 8 inserts here

\subsection{Impact of gender}

The gender of hospital users plays a role in how they rate the importance of several factors (Table 9). These tend to relate to the 'feeling' associated with the hospital (e.g., relating to natural ventilation, building orientation, and the healing environment) with women rating these as more important than men do; interestingly, the lack of toxic materials was also rated as more important by women than by men.

Table 9 inserts here

\subsection{The public or private nature of the hospital}

In evaluating whether a hospital's status as either a private or public institution makes an impact, we first compare these groups in terms of the importance of the factors (Table 10). In general, the groups rate most factors as equally important. However, public hospital users tend to rate (as being more important) those factors relating to safety for occupants and users, the plans for car parks and 
greenways, and limiting disruption from storm water. Private hospital users tend to rate the impact of natural light and strategic landscapes as more important than did public hospital users.

Table 10 inserts here

When we examine whether the users are satisfied with these factors in the hospitals, significant differences emerge (Table 11). Private hospital users are more satisfied with most of the factors, with the exception of the safety for occupants and users, materials being free from toxicity, distribution of pedestrian pathways, and limiting disruption from storm water. This probably reflects the greater budgetary constraints facing public hospitals (Duggan, 2000) which allows private facilities to invest more in order to improve their performance in relation to these factors. It is encouraging that both private and public users are equally satisfied with safety elements, and particularly with the lack of toxic materials in the hospitals; this finding provides valuable support for future hospital designs.

Table 11 inserts here

\section{DEVELOPMENT OF HOUSE OF QUALITY GREEN DESIGN (HOQGD)}

The survey results and findings from public and private hospital end-users were used to translate the 18 demanded qualities into quality elements or features for green hospital designs. Then, a HOQGD for public hospitals (Figure 1) and a separate HOQGD for private hospitals (Figure 2) were developed. The fist-level categories (in both Figure 1 and Figure 2) are derived from the GBI. The second-level categories were selected based on terms used by respondents during the pilot study and key literature (Fik, 2005; Huff, 2009; Ismail, 2013) and allocated to the most appropriate of the first-level categories. 
Figure 1 inserts here

Demanded qualities from the hospital end-users that affect the quality elements are combined in a relationship matrix to establish a green hospital design system. In the relationship matrix, three symbols describe the relationship between demand quality and quality element. The symbol ( $\boldsymbol{\square})$ represents a strong correlation (given an index value of 9); the symbol $(\Delta)$ represents some correlation (given an index value of 3); the symbol (O) refers to possible correlation (given an index value of 1); and no symbol was used when there was no correlation. The importance of the quality demands is determined by end-user queries at the hospital and investigation (using the analysis of the questionnaires). The absolute importance scores in the quality house are the sum of the results of multiplying the factor importance and correlation symbol index values.

Figure 2 inserts here

The HOQGD figures help determine the most important technical requirements that should be considered during the design process. With the importance-weighting factor included in HOQGD, the most crucial of the quality elements can be identified based on the values provided along the bottom of the figures. The relative importance percentage of every quality element can then be computed from this importance-weight system. With reference to Figure 1 and Figure 2, we see that patterns of relative importance ratings are relatively similar for both the Public and Private hospitals.

Examining the relative importance, we can see that the most crucial factors (in determining the quality in green hospital design) are controlled and enforced by the relevant authorities (as indicated by the higher values in the quality elements relating to the first-level category of 'authority'). Authorities are responsible for determining minimum requirements, a standard that must be adhered to by the 
developers and builders before a green hospital is approved or commissioned. Without tight enforcement of the law or policy, developers and builders may attempt gain more profit rather than to ensure that quality and safety features are implemented in hospital projects. Therefore, by considering green design innovations that are highly desired by the end-users, we can see that effective government policies mandating specific technical specifications - and enforcement of the requirements - will be necessary in the future.

Another crucial design feature, derived from the HOQGD to inform the prioritization of technical specifications for engineers, is the importance of materials specifications to end-users. While authorities can mandate materials specifications, effective design principles would also suggest that these factors should be incorporated into early designs, to ensure end-user satisfaction with the green hospital concept. Other important design principles that should be considered are the layout and design innovations as these factors are also considered influential to the end-user perception of the hospital, particularly in regards to the specifics of the building orientation, healing environment, and sustainable site planning and management.

\subsection{Quality demands from end-users}

From the findings among public and private hospitals' end-users (Table 4), 'safety mechanism during emergency' is the factor of greatest importance. This is followed by others, in decreasing order of importance: ‘maximize natural light', ‘natural ventilation', 'materials free from toxicity’, 'building orientation', 'healing environment', 'atmospheric condition', 'install water efficiency equipment', 'strategic landscape', and 'use of environment-friendly materials'. We suggest that many of these demands should be incorporated by authorities into regulations that will influence how designers and construction companies erect hospitals. 


\subsection{Current status of hospital satisfaction}

The hospital end-users are most satisfied with the factor 'safety mechanism during emergency'. Meanwhile, other factors (arranged in a decreasing level of satisfaction) are: 'maximize natural light', 'material free from toxicity', attractiveness of appearance', 'atmospheric condition', 'building orientation', 'natural ventilation', 'healing environment', ‘install water efficiency equipment', 'long lasting materials', ‘using rainwater harvesting', 'use environment-friendly materials', 'pedestrian pathway', and 'strategic landscape'. Private hospital users tend to be more satisfied with most of the factors than public hospital users, reflecting the budgetary constraints on public facilities (Duggan, 2000).

\subsection{Suitability and practicality of QFD to support green hospital design}

It is common that there are insufficient and incomplete definitions of expectations provided by customers or developers before the design and construction of facilities commences. Quality problems then arise and these are costly to rectify. In other cases, even while cost and specifications are being met, sudden changes occur in expectations (that were originally ill-defined). QFD works to minimize these issues by first aiding clients to define their expectations more clearly. From this study, we find that the QFD concept and technique can be used to determine customers' demands and needs, which can then inform the planning for the construction project to ensure it moves towards customer satisfaction.

It is important to note that the use of QFD is not the same as LCA. While the LCA approaches suffer from several challenges (viz., issues with credible data and the selection and evaluation of impacts that 
are difficult to compare (Ayres, 1995)), the use of QFD is not attempting to provide an objective evaluation or prioritization of criteria for implementation. Rather, the value of QFD is in translating the customer requirements into technical specifications and indicating the relative importance of factors, as determined by the end-users.

We have demonstrated that QFD can be of practical value in establishing priorities (based on end-user perceptions) in the construction industry. However, we recommended that early construction phases should involve engagement with a focus group consisting of developers, architects, engineers, and contractors with the objective of developing a QFD chart for the project. This group will try to identify the relationships between quality demands and quality elements, with facilitation from the project manager. End-user demand can be gathered from the end-user complaints data (relating to existing or similar facilities) and through market research. While it may appear challenging to satisfy customer demands in today's construction environment, QFD holds great promise as it functions to solve problems supported by the early involvement of all stakeholders. The approach breaks down the larger tasks and uncovers the relative importance of different green design factors, allowing quality to be developed and built into facilities earlier by prioritizing customer concerns. Ultimately, this approach will generate greater end-user satisfaction.

\section{CONCLUSIONS}

Merely defining quality as 'compliance to specification' is insufficient to help designers satisfy customers' desires; clients are now less likely to be satisfied unless these products or services also meet or exceed their expectations. Thus, while customers seek quality that satisfies their needs and that provides greater value, capturing these latent preferences can be challenging. To achieve this level 
of quality, QFD serves as an aid in comprehending customer demands. This study evaluates the use of QFD in designing green hospitals, determining the needs of the end-users, and translating them to technical requirements suitable for implementation at different levels of operational planning. Hence, based on end-users' demanded quality, this paper presents the QFD tool for green hospital designs for both public and private hospitals: the House of Quality Green Design (HOQGD). The concept of integrating the customers' needs into the final product is not a new concept; however, effective integration is difficult to achieve in practice. QFD provides a disciplined, structured, and systematic method to achieve integration of customer needs, using quality charts. It helps to identify the constituent elements of a green hospital and translates the needs of the hospital end-users to construction firms, in terms of features that designers can understand and act on. The use of the quality matrix interprets demand quality to generate the project quality elements and technical specifications.

Despite careful design of the study, the sampling method may create some biases. One limitation is that while the respondents were selected randomly from among the users of the facility, there were no responses amongst users of public hospitals indicating respondents had 'no formal education' and only one respondent that indicated they had only 'primary education'. There are no responses with 'no formal education' and 'primary education' in private hospitals. The level of education amongst respondents may be higher than anticipated because all the hospitals (where we sampled the end-users at) are located in Klang Valley, which is the most developed region in Malaysia, thus most of the medical staff, patients, and visitors have better educational background than people from other regions in Malaysia. However, the level of education of respondents in both cases is relatively consistent with the overall education of the population in this area, where most people have had at least a secondary education if not college/university education. Further studies should extended this research to lessdeveloped regions in Malaysia and elsewhere in the tropics. 
Future studies should be conducted to determine the specific problems encountered during both design and construction phases of hospitals. Since this study is involved in the design phase of a hospital's technical elements, such research would extend our results and also evaluate tertiary hospital facilities. A continued project to apply the developed HOQGD on a several cases would enable empirical evaluation of the improvements generated by the use of QFD on construction projects; e.g., evaluating the magnitude of cost reductions (due to designs changes or delays as the design changes to accommodate end-user needs), relative to conventional methods used during the design process.

\section{REFERENCES}

Abdul-Rahman, H., Wang, C., Wood, L.C., Khoo, Y.M. (2014). Defects in affordable housing projects in Klang Valley, Malaysia. Journal of Performance of Constructed Facilities, 28(2), 272-285.

Abdul-Rahman, H., Wang, C., Wood, L.C., Low, S.F. (2012). Negative impact induced by foreign workers: Evidence in Malaysian construction sector. Habitat International, 36(4), 433-443.

Akao, Y. (1990). Quality Function Deployment: Integrating customer requirements into product design. G.H. Mazur: Productivity Press.

Aliagha, G. U., Hashim, M., Sanni, A. O., Ali, K. N. (2013). Review of green building demand factors for malaysia. Journal of Energy Technologies and Policy, 3(11), 471-478.

Ayres, R.U. (1995). Life cycle analysis: A critique. Resources, Conservation and Recycling, 14(3-4), pp. 199-223.

Construction Industry Development Board (2000). Malaysian construction industry: Technology foresight report. Bangkok: CIDB Malaysia and APEC Technology Foresight Centre.

Conover W.J. (1999). Practical nonparametric statistics (3rd ed). New York: Wiley.

Davidson, J. (2013). A proposal for the future of vernacular architecture studies. Open House International, 38(2), 18-22. 
Dijkstra, L., van der Bij, H. (2002). Quality function deployment in healthcare. International Journal of Quality \& Reliability Management, 19(1), 67-89.

Dinneen, L.C., Blakesley, B.C. (1973). Algorithm AS 62: A generator for the sampling distribution of the Mann- Whitney U Statistic. Journal of the Royal Statistical Society. Series C (Applied Statistics), 22(2), 269-273.

Dong, C.S., Zhang, C., Wang, B. (2003). Integration of green quality function deployment and fuzzy multi-attribute utility theory-based cost estimation for environmentally conscious product development. International Journal of Environmentally Conscious Design \& Manufacturing, 11(1), $12-28$.

Duggan, M. (2000). Hospital ownership and public medical spending (Working Paper No. 7789), National Bureau of Economic Research, available at: http://www.nber.org/papers/w7789 (accessed 22 May 2015).

Dunn, O.J. (1964). Multiple comparisons using rank sums. Technometrics, 6(3), 241-252.

Fik, D. (2005). Green Design and Organizational Sustainability. London: Haworth.

Gargione, L.A. (1999). Using Quality Function Deployment (QFD) in the design phase of an apartment construction project. IGLC-7 (pp. 357-368). CA, USA: University of California.

Gross, R., Sasson, Y., Zarhy Architect, M., Zohar, J. (1998). Healing environment in psychiatric hospital design. General Hospital Psychiatry, 20(2), 108-114.

Gudiene, N., Banaitis, A., Banaitienè, N. (2013). Evaluation of critical success factors for construction projects: an empirical study in Lithuania. International Journal of Strategic Property Management, 17(1), 21-31.

Guinta, L.R., Praizler, N.C. (1993). The QFD book: The team approach to solving problems and satisfying customers through Quality Function Deployment. New York: Amacom. 
Han, K., Shin, J. (2014). An integrated quality function deployment and capital budgeting methodology for occupational safety and health as a systems thinking approach: The case of the construction industry. Accident Analysis \& Prevention, 68, 42-56.

Haron, N. A., Abdul-Rahman, H., Wang, C., \& Wood, L. C. (2015). Quality function deployment (QFD) modelling to enhance industrialized building system adoption in housing projects. Total Quality Management \& Business Excellence, 26(7-8), 703-718.

Hauser, J.R. (1993). How Puritan-Bennet used the house of quality. Sloan Management Review, 34(3), $61-70$.

Heschong, L., Wright, D.R.L., Okura, S. (2002). Daylighting impacts on retail sales performance. Journal of the Illuminating Engineering Society, 31(2), 21-25.

Hauser, J.R., Clausing, D. (1988). The house of quality. Harvard Business Review, 3, 63-73.

Hsu, T.S., Pan, C.H., Yang, C.L. (1997). A QFD-based approach for product positioning. Journal of Chinese Institute of Industrial Engineers, 14, 209-216.

Huff, W. (2009). Water efficiency and hospitals. London: Plumbing System \& Design.

Ibrahim, D., Adnan, M., Arif, H., Hikmet, K.T. (2010). Global warming: Engineering solutions. New York: Springer.

Ismail, M.R. (2013). Quiet environment: Acoustics of vertical green wall systems of the Islamic urban form. Frontiers of Architectural Research, 2(2), 162-177.

Kamvysi, K., Gotzamani, K., Andronikidis, A., Georgiou, A.C. (2014). Capturing and prioritizing students' requirements for course design by embedding Fuzzy-AHP and linear programming in QFD. European Journal of Operational Research, 237(3), 1083-1094.

Karsak, E.E., Dursun, M. (2014). An integrated supplier selection methodology incorporating QFD and DEA with imprecise data. Expert Systems with Applications, 41(16), 6995-7004.

Lim, P.C., Tang, N.K.H. (2000). The development of a model for total quality healthcare. Managing Service Quality: An International Journal, 10(2), 103-111. 
Liu, J., London, K. (2013). Modelling housing supply and monetary policy within the context of global economic turbulence. International Journal of Strategic Property Management, 17(1), 1-20.

Low, S.P., Yeap, L. (2001). Quality function deployment in design/build projects. Journal of Architectural Engineering, 7(2), 30-39.

Mao, D., Zhou, K., Zheng, S.J., Liu, Y.D., Liu, Y.P. (2011). Research on evaluation system of green building in China. Advanced Materials Research, 224, 159-163.

McGraw-Hill Construction (2008). Key trends in the European and U.S. construction marketplace SmartMarket Report. New York: McGraw-Hill Construction.

McLellan, A. (1994). Future Positive. New Builder, 17(2), 26-28.

Moldovan, L. (2014). QFD employment for a new product design in a mineral water company. Procedia Technology, 12, 462-468.

Morden, J. (2011). Malaysia to green its public hospitals. Asia Pacific Futuregov. Accessed on $5^{\text {th }}$ August 2014.

Ng, K.L. (1999). Quality Function Deployment (QFD) in construction: Application of QFD concept and technique in private school design. Kuala Lumpur: UM Press.

Nunnally, J.C .(1978). Psychometric theory (2nd ed.). New York: McGraw-Hill.

Ortiz, O., Castells, F., Sonnemann, G. (2009). Sustainability in the construction industry: A review of recent developments based on LCA. Construction and Building Materials, 23(1), 28-39.

Raharjo, H., Brombacher, A.C., Xie, M. (2008). Dealing with subjectivity in early product design phase: a systematic approach to exploit quality function deployment potentials. Computers and Industrial Engineering, 55, 253-278.

Ramesh, T., Prakash, R., Shukla, K.K. (2010). Life cycle energy analysis of buildings: An overview. Energy and Buildings, 42(10), 1592-1600.

Salant, P., Dillman, D.A. (1994). How to conduct your own survey. Michigan: Wiley. 
Shi, Q., Xie, X. (2009). A fuzzy-QFD approach to the assessment of green construction alternatives based on value engineering. Proceedings of the International Conference on Management and Service Science, MASS 2009, 20-22 September 2009, Wuhan/Beijing, China, 1-6.

Stevenson, W.J. (2007). Operations management. 9th ed. New York: McGraw-Hill.

Woodward, D.G. (1997). Life cycle costing—Theory, information acquisition and application. International Journal of Project Management, 15(6), 335-344.

Wübbenhorst, K.L. (1986). Life cycle costing for construction projects. Long Range Planning, 19 (4), 87-97.

Zaim, S., Sevkli, M., Camgöz-Akdağ, H., Demirel, O.F., Yayla, A.Y., Delen, D. (2014). Use of ANP weighted crisp and fuzzy QFD for product development. Expert Systems with Applications, 41(9), 4464-4474. 
Table 1: Demands for green hospital design quality based on the six categories identified in GBI

(CBRE, 2010)

\begin{tabular}{ll}
\hline DEMAND QUALITY & \\
\hline Energy efficiency & Natural ventilation \\
& Natural light \\
& Renewable energy \\
& Building orientation \\
\hline Indoor environmental quality & Healing environment \\
& Atmospheric conditions \\
& Safe for occupants and users \\
\hline Sustainable site planning \& & Strategic landscaping \\
management & Plan for car parks and greenways \\
& Pedestrian pathway with plants \\
\hline Materials \& resources & Use of environment-friendly \\
& materials \\
& Materials free from toxic chemicals \\
& Long lasting materials \\
\hline Water efficiency & Install water efficient equipment \\
& Use rainwater harvesting \\
& Limit disruption of storm water \\
& flows \\
\hline Innovation & Attractiveness of appearance \\
& Existence of safety mechanism \\
\hline
\end{tabular}


Table 2: Items relating to quality elements required to establish and enforce green hospital design

\begin{tabular}{ll}
\hline QUALITY ELEMENT & \\
\hline Design & Sufficient layout \\
& Innovative design \\
& Construction method \\
\hline Environmental condition & Ventilation \\
& Lighting \\
& Sufficient direction \\
& Openness space \\
& Air pollution \\
& Natural resources \\
\hline Authority & Strict enforcement \\
& Standard requirement \\
& Material specifications \\
& Quality builders \\
\hline
\end{tabular}


Table 3: Profile of respondents for public and private hospital

\begin{tabular}{|c|c|c|c|c|}
\hline \multirow[b]{2}{*}{ Profile of Respondents } & \multicolumn{2}{|c|}{ Public Hospital } & \multicolumn{2}{|c|}{ Private Hospital } \\
\hline & $\begin{array}{c}\text { Frequency } \\
(n=86)\end{array}$ & Percent & $\begin{array}{c}\text { Frequency } \\
(n=63)\end{array}$ & Percent \\
\hline \multicolumn{5}{|l|}{ Gender } \\
\hline Female & 55 & 64.0 & 40 & 63.5 \\
\hline Male & 31 & 36.0 & 23 & 36.5 \\
\hline \multicolumn{5}{|l|}{ Age } \\
\hline 20 and Younger & 11 & 12.8 & 9 & 14.3 \\
\hline $21-29$ & 40 & 46.5 & 36 & 57.1 \\
\hline $30-40$ & 26 & 30.2 & 15 & 23.8 \\
\hline Above 40 & 9 & 10.5 & 3 & 4.8 \\
\hline \multicolumn{5}{|l|}{ Position in Hospital } \\
\hline Medical Staff & 23 & 26.7 & 13 & 20.6 \\
\hline Hospital Worker & 8 & 9.3 & 4 & 6.3 \\
\hline Patient & 19 & 22.1 & 23 & 36.5 \\
\hline Visitor & 36 & 41.9 & 23 & 36.5 \\
\hline \multicolumn{5}{|l|}{ Education Level } \\
\hline No Formal Education & 0 & 0.0 & 0 & 0.0 \\
\hline Primary Education & 1 & 1.2 & 0 & 0.0 \\
\hline Secondary Education & 23 & 26.7 & 17 & 27.0 \\
\hline College/University & 62 & 72.1 & 46 & 73.0 \\
\hline \multicolumn{5}{|l|}{ Frequency of Visit } \\
\hline Everyday & 29 & 33.7 & 15 & 23.8 \\
\hline Once a week & 4 & 4.7 & 3 & 4.8 \\
\hline Once in every 2 weeks & 5 & 5.8 & 3 & 4.8 \\
\hline Once a month or less & 25 & 29.1 & 19 & 30.2 \\
\hline Others & 23 & 26.7 & 23 & 36.5 \\
\hline
\end{tabular}


Table 4: Brief ranking of the importance of factors affecting the quality of the Green Hospital Design (public and private hospitals)

\section{Factors Affect the Quality of a Green Hospital Design}

\section{Public Hospital Private Hospital}

\begin{tabular}{lcccc} 
& Mean & Ranking & Mean & Ranking \\
\hline Safety mechanism during emergency & 4.56 & 1 & 4.57 & 1 \\
\hline Safe for occupants and users & 4.52 & 2 & 4.24 & 11 \\
\hline Materials free from toxic chemicals & 4.50 & 3 & 4.35 & 7 \\
\hline Atmospheric condition & 4.45 & 4 & 4.32 & 9 \\
\hline Natural ventilation & 4.44 & 5 & 4.46 & 4 \\
\hline Plan for car parks and greenways & 4.43 & 6 & 4.10 & 16 \\
\hline Healing environment & 4.41 & 7 & 4.52 & 2 \\
\hline Install water efficient equipment & 4.38 & 8 & 4.44 & 5 \\
\hline Attractiveness of appearance & 4.38 & 8 & 4.22 & 13 \\
\hline Building orientation & 4.34 & 10 & 4.35 & 7 \\
\hline Pedestrian pathway & 4.27 & 11 & 4.16 & 14 \\
\hline Strategic landscape & 4.26 & 12 & 4.51 & 3 \\
\hline Use an environment-friendly materials & 4.24 & 13 & 4.30 & 10 \\
\hline Long lasting materials & 4.21 & 14 & 4.11 & 15 \\
\hline Renewable energy & 4.14 & 15 & 4.24 & 11 \\
\hline Limit disruption of storm water & 4.12 & 16 & 3.60 & 18 \\
\hline Using rainwater harvesting & 3.99 & 17 & 4.03 & 17 \\
\hline Maximize natural light & 3.98 & 18 & 4.44 & 5 \\
\hline
\end{tabular}


Table 5: Significant results where age groups rated the importance of factors differently

\begin{tabular}{|l|l|l|}
\hline Factor & Test statistics & Differences (5=strongly agree; $1=$ strongly disagree) \\
\hline Building orientation & $\chi 2(3)=10.149, \mathrm{p}=0.017$ & Age 21-29 (Median=5); others Median=4.0) \\
\hline Healing environment & $\chi 2(3)=10.898, \mathrm{p}=0.012$ & Age 20 or younger (Median=4.0); others Median=5.0) \\
\hline $\begin{array}{l}\text { Safe for occupants } \\
\text { and users }\end{array}$ & $\chi 2(3)=8.803, \mathrm{p}=0.032$ & Age 21-29 and 30-40 (Median=5.0); others (median=4.0) \\
\hline Appearance & $\chi 2(3)=8.560, \mathrm{p}=0.036$ & Age 30-40 (Median=5.0); others Median=4.0) \\
\hline
\end{tabular}


Table 6: Significant results where groups of the position in hospital rated the importance of factors

\section{differently}

\begin{tabular}{|c|c|c|}
\hline Factor & Test statistics & Differences (5=strongly agree; 1=strongly disagree) \\
\hline Natural ventilation & $\chi 2(3)=9.061, p=0.028$ & $\begin{array}{l}\text { Visitors }(\text { Median=4.0) and Medical Staff }(\text { Median=5.0) } \\
(\mathrm{p}=0.027)\end{array}$ \\
\hline Building orientation & $\chi 2(3)=19.853, p=0.000$ & $\begin{array}{l}\text { Hospital Workers (Median=4.0) and Patients (Median=5.0) } \\
(\mathrm{p}=0.032) \\
\text { Hospital Workers (Median=4.0) and Medical Staff } \\
(\text { Median=5.0 }(\mathrm{p}=0.010) \\
\text { Visitors (Median=4.0) and Patients (Median=5.0) }(\mathrm{p}=0.022) \\
\text { Visitors (Median=4.0) and Medical Staff (Median=5.0) } \\
(\mathrm{p}=0.004)\end{array}$ \\
\hline Healing environment & $\chi 2(3)=10.282, p=0.016$ & $\begin{array}{l}\text { Hospital Workers (Median=4.0) and Medical Staff } \\
(\text { Median=5.0) }(\mathrm{p}=0.011)\end{array}$ \\
\hline Strategic landscape & $\chi 2(3)=14.743, p=0.002$ & $\begin{array}{l}\text { Medical Staff (Median=4.0) and Patients (Median=5.0) } \\
(p=0.003)\end{array}$ \\
\hline Appearance & $\chi 2(3)=14.658, p=0.002$ & $\begin{array}{l}\text { Visitors (Median=4.0) and Medical Staff (Median=5.0) } \\
(\mathrm{p}=0.002)\end{array}$ \\
\hline
\end{tabular}


Table 7: Significant results where groups that visit the hospital at different frequencies rated the importance of factors differently

\begin{tabular}{|l|l|l|}
\hline Factor & Test statistics & Differences (5=strongly agree; 1=strongly disagree) \\
\hline Healing environment & $\chi 2(3)=13.158, \mathrm{p}=0.004$ & $\begin{array}{l}\text { Every 1-2 weeks (Median=4) and Every day (Median=5) } \\
(\mathrm{p}=0.003) \\
\text { Every } 1-2 \text { weeks (Median=4) and others (Median=5) } \\
(\mathrm{p}=0.025)\end{array}$ \\
\hline $\begin{array}{l}\text { Safe for occupants } \\
\text { and users }\end{array}$ & $\chi^{2(3)=9.055, \mathrm{p}=0.029}$ & $\begin{array}{l}\text { Every 1-2 weeks (Median=4) and Every day (Median=5) } \\
(\mathrm{p}=0.019)\end{array}$ \\
\hline Strategic landscape & $\chi^{2(3)=14.710, p=0.002}$ & Every day (Median=4) and Others (Median=5.0) $(\mathrm{p}=0.001)$ \\
\hline Appearance & $\chi^{2(3)=9.963, p=0.019}$ & $\begin{array}{l}\text { Once a month or less (Median=4) and every day (Median=5) } \\
(\mathrm{p}=0.022)\end{array}$ \\
\hline
\end{tabular}


Table 8: Significant results where groups with different levels of education rated the importance of factors differently

\begin{tabular}{|l|l|}
\hline Factor & Test statistics \\
\hline Building orientation & $\mathrm{U}=2,977, \mathrm{z}=3.628, \mathrm{p}=0.000$ \\
\hline Healing environment & $\mathrm{U}=2,626.5, \mathrm{z}=1.985, \mathrm{p}=0.047$ \\
\hline Safe for occupants and users & $\mathrm{U}=2,689, \mathrm{z}=2.262, \mathrm{p}=0.024$ \\
\hline Appearance & $\mathrm{U}=2,632, \mathrm{z}=1.980, \mathrm{p}=0.048$ \\
\hline
\end{tabular}


Table 9: Significant results where men and women rated the importance of factors differently

\begin{tabular}{|l|l|}
\hline Factor & Test statistics \\
\hline Natural ventilation & $\mathrm{U}=2.120 .5, \mathrm{z}=-1.981, \mathrm{p}=0.048$ \\
\hline Building orientation & $\mathrm{U}=1,813.5, \mathrm{z}=-3.320, \mathrm{p}=0.001$ \\
\hline Healing environment & $\mathrm{U}=1,933.5, \mathrm{z}=-2.824, \mathrm{p}=0.005$ \\
\hline Materials free from toxic & $\mathrm{U}=1,882.5, \mathrm{z}=-3.019, \mathrm{p}=0.003$ \\
\hline
\end{tabular}


Table 10: Significant results where users of Private and Public hospitals rated the importance of factors

\section{differently}

\begin{tabular}{|l|l|l|}
\hline Factors & Test statistics & Differences \\
\hline Natural light & $\begin{array}{l}\mathrm{U}=3,530.5, \mathrm{z}=3.62, \mathrm{p}= \\
0.000\end{array}$ & $\begin{array}{l}\text { Public (Mean=3.9767; Median=4.0) vs } \\
\text { Private (Mean = 4.444; Median=4.0) }\end{array}$ \\
\hline Safe to occupants and users & $\begin{array}{l}\mathrm{U}=2,071.5, \mathrm{z}=-2.744, \mathrm{p}= \\
0.006\end{array}$ & $\begin{array}{l}\text { Public (Mean=4.5233; Median=5.0) vs } \\
\text { Private (Mean = 4.2381; Median=4.0) }\end{array}$ \\
\hline Strategic landscape & $\begin{array}{l}\mathrm{U}=3,288, \mathrm{z}=2.515, \mathrm{p}= \\
0.012\end{array}$ & $\begin{array}{l}\text { Public (Mean=4.2558; Median=4.0) vs } \\
\text { Private (Mean = 4.5079; Median=5.0) }\end{array}$ \\
\hline $\begin{array}{l}\text { Plan for car parks and } \\
\text { greenways }\end{array}$ & $\begin{array}{l}\mathrm{U}=2,155.5, \mathrm{z}=-2.323, \mathrm{p}= \\
0.020\end{array}$ & $\begin{array}{l}\text { Public (Mean=4.4302; Median=5.0) vs } \\
\text { Private (Mean = 4.0952; Median=4.0) }\end{array}$ \\
\hline $\begin{array}{l}\text { Limit disruption of storm } \\
\text { water }\end{array}$ & $\begin{array}{l}\mathrm{U}=1,732, \mathrm{z}=-4.247, \mathrm{p}= \\
0.000\end{array}$ & $\begin{array}{l}\text { Public (Mean=4.1163; Median=4.0) vs } \\
\text { Private (Mean = 3.6032; Median=4.0) }\end{array}$ \\
\hline
\end{tabular}


Table 11: Significant results where users of Private and Public hospitals rated their satisfaction with

\section{factors differently}

\begin{tabular}{|c|c|c|}
\hline Factors & Test statistics & Differences \\
\hline Natural ventilation & $\begin{array}{l}\mathrm{U}=3,513.5, \mathrm{z}=3.374, \mathrm{p}= \\
0.001\end{array}$ & $\begin{array}{l}\text { Public (Mean= 3.3372; Median=3.0) vs Private } \\
(\text { Mean= 3.7778; Median=4.0) }\end{array}$ \\
\hline Natural light & $\begin{array}{l}\mathrm{U}=3,321, \mathrm{z}=2.574, \mathrm{p}= \\
0.010\end{array}$ & $\begin{array}{l}\text { Public (Mean= 3.5233; Median=4.0) vs Private } \\
(\text { Mean= 3.8254; Median=4.0) }\end{array}$ \\
\hline Renewable energy & $\begin{array}{l}U=3,675, z=3.905, p= \\
0.000\end{array}$ & $\begin{array}{l}\text { Public (Mean=2.8953; Median=3.0) vs Private } \\
\text { (Mean=3.5079; Median=4.0) }\end{array}$ \\
\hline Building orientation & $\begin{array}{l}U=3,555, z=3.538, p= \\
0.000\end{array}$ & $\begin{array}{l}\text { Public (Mean=3.3488; Median=3.5) vs Private } \\
\text { (Mean=3.8571; Median=4.0) }\end{array}$ \\
\hline Healing environment & $\begin{array}{l}U=3,639.5, \mathrm{z}=4.180, \mathrm{p}= \\
0.000\end{array}$ & $\begin{array}{l}\text { Public (Mean=3.3140; Median=4.0) vs Private } \\
(\text { Mean=3.8889; Median=4.0) }\end{array}$ \\
\hline Atmospheric condition & $\begin{array}{l}\mathrm{U}=3,189.5, \mathrm{z}=2.018, \mathrm{p}= \\
0.044\end{array}$ & $\begin{array}{l}\text { Public }(\text { Mean=3.3953; Median=4.0) vs Private } \\
(\text { Mean=3.6825; Median=4.0) }\end{array}$ \\
\hline Strategic landscape & $\begin{array}{l}\mathrm{U}=3,607.5, \mathrm{z}=3.613, \mathrm{p}= \\
0.000\end{array}$ & $\begin{array}{l}\text { Public (Mean=2.9767; Median=3.0) vs Private } \\
\text { (Mean=3.5556; Median=4.0) }\end{array}$ \\
\hline $\begin{array}{l}\text { Plan for car parks and } \\
\text { greenways }\end{array}$ & $\begin{array}{l}U=3,385, z=2.672, p= \\
0.008\end{array}$ & $\begin{array}{l}\text { Public (Mean=2.6744; Median=3.0) vs Private } \\
\text { (Mean=3.2063; Median=3.0) }\end{array}$ \\
\hline $\begin{array}{l}\text { Use an environment-friendly } \\
\text { materials }\end{array}$ & $\begin{array}{l}\mathrm{U}=3,221, \mathrm{z}=2.077, \mathrm{p}= \\
0.038\end{array}$ & $\begin{array}{l}\text { Public (Mean=2.9767; Median=3.0) vs Private } \\
\text { (Mean= 3.2381; Median=3.0) }\end{array}$ \\
\hline Long lasting materials & $\begin{array}{l}U=3,317, z=2.507, p= \\
0.012\end{array}$ & $\begin{array}{l}\text { Public (Mean=3.2442; Median=3.0) vs Private } \\
\text { (Mean= 3.5714; Median=4.0) }\end{array}$ \\
\hline $\begin{array}{l}\text { Install water efficient } \\
\text { equipment }\end{array}$ & $\begin{array}{l}\mathrm{U}=3,524.5, \mathrm{z}=3.510, \mathrm{p}= \\
0.000\end{array}$ & $\begin{array}{l}\text { Public (Mean=3.2907; Median=4.0) vs Private } \\
(\text { Mean=3.7937; Median=4.0) }\end{array}$ \\
\hline Using rainwater harvesting & $\begin{array}{l}U=3,387.5, z=2.765, p= \\
0.006\end{array}$ & $\begin{array}{l}\text { Public (Mean=3.1163; Median=3.0) vs Private } \\
\text { (Mean=3.4762; Median=4.0) }\end{array}$ \\
\hline Appearance & $\begin{array}{l}\mathrm{U}=3,490.5, \mathrm{z}=3.824, \mathrm{p}= \\
0.000\end{array}$ & $\begin{array}{l}\text { Public (Mean=3.5116; Median=4.0) vs Private } \\
(\text { Mean=3.9841; Median=4.0) }\end{array}$ \\
\hline Safety mechanism & $\begin{array}{l}\mathrm{U}=3,634, \mathrm{z}=3.961, \mathrm{p}= \\
0.000\end{array}$ & $\begin{array}{l}\text { Public }(\text { Mean=3.5814; Median=4.0) vs Private } \\
(\text { Mean=4.0635; Median=4.0) }\end{array}$ \\
\hline
\end{tabular}




\begin{tabular}{|c|c|c|c|c|c|c|c|c|c|c|c|c|c|c|c|}
\hline \multirow[b]{2}{*}{ DEMAND QUALITY } & \multirow[t]{2}{*}{ QUALITY ELEMENT } & \multirow{2}{*}{ 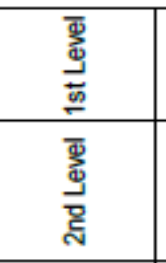 } & \multicolumn{3}{|c|}{ DESIGN } & \multicolumn{6}{|c|}{ ENVIRONMENTAL CONDITION } & \multicolumn{4}{|c|}{ AUTHORITY } \\
\hline & & & $\begin{array}{l}\text { 志 } \\
\text { 总 } \\
\text { 空 }\end{array}$ & 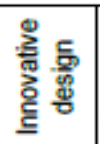 & 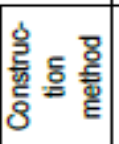 & 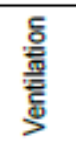 & $\begin{array}{l}\text { 辜 } \\
\text { 憘 }\end{array}$ & 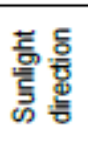 & 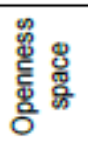 & $\begin{array}{l}\text { 올 } \\
\frac{5}{0} \\
\frac{2}{5}\end{array}$ & 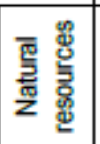 & 흘 흥 홍 & 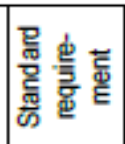 & 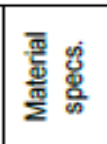 & 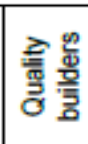 \\
\hline 1st Level & 2nd Level & Importance & & & & & & & & & & & & & \\
\hline \multirow{4}{*}{$\begin{array}{c}\text { ENERGY } \\
\text { EFFICIENCY }\end{array}$} & Natural ventilation & \begin{tabular}{l|l}
4.44 \\
\end{tabular} & & & & $\square$ & & & $\triangle$ & & & $\triangle$ & O & & \\
\hline & \begin{tabular}{|l|} 
Natural light \\
\end{tabular} & 3.98 & & & & & $\square$ & $\square$ & 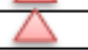 & & & $\triangle$ & 0 & & \\
\hline & Renewable energy & 4.14 & & & & & & $\triangle$ & & & & $\triangle$ & 0 & & \\
\hline & Building orientation & 4.34 & $\square$ & & & & & & 0 & & & & & & O \\
\hline \multirow{3}{*}{$\begin{array}{c}\text { INDOOR } \\
\text { ENVIRONMENTAL } \\
\text { QUALITY }\end{array}$} & Healing environment & 4.41 & & $\square$ & $\triangle$ & 0 & & & & & & & $\triangle$ & & $\triangle$ \\
\hline & Atmospheric conditions & 4.45 & & & & $\square$ & & & $\triangle$ & & & & & & \\
\hline & Safe for occupants and users & 4.52 & & & & & & & & & & $\square$ & $\square$ & & $\triangle$ \\
\hline \multirow{3}{*}{\begin{tabular}{|c|} 
SUSTAINABLE SITE \\
PLANNING \& \\
MANAGEMENT
\end{tabular}} & Strategic landscaping & 4.26 & $\square$ & & & & O & 0 & & & & & & & \\
\hline & Plan for a car parks and greenways & 4.43 & $\square$ & $\triangle$ & & & & & & & & & $\square$ & & \\
\hline & \begin{tabular}{|l} 
Pedestrian pathway with plants \\
\end{tabular} & 4.27 & $\square$ & $\vec{\Delta}$ & & & & & & & & & $\square$ & & \\
\hline \multirow{3}{*}{$\begin{array}{l}\text { MATERIALS \& } \\
\text { RESOURCES }\end{array}$} & Use of environment - friendly materials & 4.24 & & & & & & & & & $\square$ & $\square$ & $\triangle$ & $\square$ & \\
\hline & Materials free from toxic chemicals & 4.50 & & & & & & & & & $\square$ & $\square$ & $\Delta$ & $\square$ & \\
\hline & \begin{tabular}{|l|} 
Long lasting materials \\
\end{tabular} & 4.21 & & & & & & & & & $\square$ & $\square$ & $\triangle$ & $\square$ & \\
\hline \multirow{3}{*}{$\begin{array}{c}\text { WATER } \\
\text { EFFICIENCY }\end{array}$} & Install water efficient equipment & 4.38 & & & & & & & & & & & $\triangle$ & $\bar{\square}$ & \\
\hline & Using rainwater harvesting & 3.99 & & & $\square$ & & & & & $\triangle \Delta$ & & & $\vec{\Delta}$ & & \\
\hline & Limit distruption of storm water flows & 4.12 & & & $\square$ & & & & & $\triangle$ & & & $\triangle$ & & \\
\hline \multirow[t]{2}{*}{ INNOVATION } & Attractiveness of appearance & 4.38 & & $\square$ & $\bar{O}$ & & & & & & & & & & \\
\hline & Existence of safety mechanism & 4.56 & & $\bar{\square}$ & $\triangle$ & & & & & & & $\square$ & $\square$ & & 0 \\
\hline \multicolumn{3}{|c|}{ Absolute importance } & 155.7 & 146.3 & 104.3 & 84.4 & 40.1 & 52.5 & 43.0 & 24.3 & 116.6 & 236.0 & 262.1 & 156.0 & 35.7 \\
\hline \multicolumn{3}{|c|}{ Relative importance (\%) } & 10.7 & 10.0 & 7.2 & 5.8 & 2.8 & 3.6 & 3.0 & 1.7 & \begin{tabular}{|c|}
8.0 \\
\end{tabular} & 16.2 & 18.0 & 10.7 & 2.5 \\
\hline
\end{tabular}

\begin{tabular}{|ccl|}
\hline Symbol & Correlation Factor \\
$\square$ & Point & Correlation \\
$\triangle$ & 9 & Strong \\
$\square$ & 3 & Some \\
\hline & 1 & Possible \\
\hline
\end{tabular}

Figure 1. House of Quality Green Design (HOQGD) for Public Hospitals 


\begin{tabular}{|c|c|c|c|c|c|c|c|c|c|c|c|c|c|c|c|}
\hline \multirow[b]{2}{*}{ DEMAND QUALITY } & \multirow[t]{2}{*}{ QUALITY ELEMENT } & \multirow{2}{*}{ 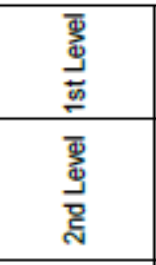 } & \multicolumn{3}{|c|}{ DESIGN } & \multicolumn{6}{|c|}{ ENVIRONMENTAL CONDITION } & \multicolumn{4}{|c|}{ AUTHORITY } \\
\hline & & & $\begin{array}{l}\text { 点 } \\
\text { 总 } \\
\text { 产 } \\
\text { 畜 }\end{array}$ & 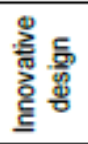 & 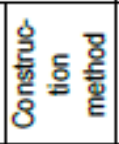 & 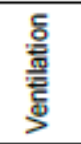 & $\begin{array}{l}\text { 罯 } \\
\text { 夏 }\end{array}$ & 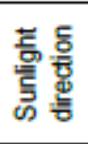 & 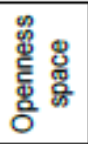 & 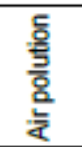 & 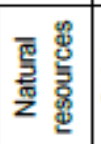 & 占 & 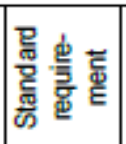 & 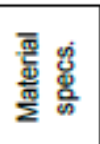 & 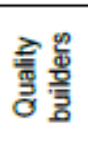 \\
\hline 1st Level & 2nd Level & Importance & & & & & & & & & & & & & \\
\hline \multirow{4}{*}{$\begin{array}{c}\text { ENERGY } \\
\text { EFFICIENCY }\end{array}$} & Natural ventilation & 4.46 & & & & $\square$ & & & $\triangle$ & & & $\triangle$ & $\mathrm{O}$ & & \\
\hline & \begin{tabular}{|l|} 
Natural light \\
\end{tabular} & 4.44 & & & & & $\square$ & $\square$ & $\vec{\Delta}$ & & & $\vec{\Delta}$ & O & & \\
\hline & Renewable energy & 4.24 & & & & & & $\triangle$ & & & & $\triangle$ & O & & \\
\hline & Building orientation & 4.35 & $\square$ & & & & & & O & & & & & & 0 \\
\hline \multirow{3}{*}{\begin{tabular}{|c|} 
INDOOR \\
ENVIRONMENTAL \\
QUALITY
\end{tabular}} & Healing environment & 4.52 & & $\square$ & $\triangle$ & 0 & & & & & & & $\triangle$ & & $\triangle$ \\
\hline & Atmospheric conditions & 4.32 & & & & $\square$ & & & $\triangle$ & & & & & & \\
\hline & Safe for occupants and users & 4.24 & & & & & & & & & & $\square$ & $\square$ & & $\triangle$ \\
\hline \multirow{3}{*}{$\begin{array}{c}\text { SUSTAINABLE SITE } \\
\text { PLANNING \& } \\
\text { MANAGEMENT }\end{array}$} & Strategic landscaping & 4.51 & $\square$ & & & & O & 0 & & & & & & & \\
\hline & \begin{tabular}{|l} 
Plan for a car parks and greenways \\
\end{tabular} & 4.10 & $\square$ & $\triangle$ & & & & & & & & & $\square$ & & \\
\hline & Pedestrian pathway with plants & 4.16 & $\square$ & $\triangle$ & & & & & & & & & $\square$ & & \\
\hline \multirow{3}{*}{$\begin{array}{l}\text { MATERIALS \& } \\
\text { RESOURCES }\end{array}$} & Use of environment - friendly materials & 4.30 & & & & & & & & & $\square$ & $\square$ & $\triangle$ & $\square$ & \\
\hline & Materials free from toxic chemicals & 4.35 & & & & & & & & & $\square$ & $\square$ & $\Delta$ & $\square$ & \\
\hline & \begin{tabular}{|l|} 
Long lasting materials \\
\end{tabular} & 4.11 & & & & & & & & & $\square$ & $\square$ & $\triangle$ & $\square$ & \\
\hline \multirow{3}{*}{$\begin{array}{c}\text { WATER } \\
\text { EFFICIENCY }\end{array}$} & Install water efficient equipment & 4.44 & & & & & & & & & & & $\triangle$ & $\bar{\square}$ & \\
\hline & Using rainwater harvesting & 4.03 & & & $\square$ & & & & & $\triangle D$ & & & $\triangle$ & & \\
\hline & \begin{tabular}{|l} 
Limit distruption of storm water flows \\
\end{tabular} & 3.60 & & & $\bar{\square}$ & & & & & $\triangle$ & & & $\triangle$ & & \\
\hline \multirow[t]{4}{*}{ INNOVATION } & Attractiveness of appearance & 4.22 & & $\square$ & $\overline{0}$ & & & & & & & & & & \\
\hline & Existence of safety mechanism & 4.57 & & $\bar{\square}$ & $\triangle$ & & & & & & & $\square$ & $\square$ & & O \\
\hline & \multicolumn{2}{|c|}{ Absolute importance } & 154.1 & 144.6 & 100.1 & 83.5 & 44.5 & 57.2 & 44.0 & 22.9 & \begin{tabular}{|l|l|}
114.8 \\
\end{tabular} & 233.6 & 254.8 & 154.8 & 35.2 \\
\hline & \multicolumn{2}{|c|}{ Relative importance (\%) } & 10.7 & 10.0 & 6.9 & 5.8 & 3.1 & 4.0 & 3.0 & 1.6 & 7.9 & 16.2 & 17.6 & 10.7 & 2.4 \\
\hline
\end{tabular}

\begin{tabular}{|ccl|}
\hline & \multicolumn{2}{c|}{ Correlation Factor } \\
Symbol & Point & Correlation \\
$\square$ & 9 & Strong \\
$\triangle$ & 3 & Some \\
$\square$ & 1 & Possible \\
\hline
\end{tabular}

Figure 2. House of Quality Green Design (HOQGD) for Private Hospital 
This is the post-print (i.e., final draft, post-refereeing) of the article:

Wood, L. C., Wang, C., Abdul-Rahman, H., \& Abdul-Nasir, N. S. J. (in press). Green hospital design: Integrating quality function deployment and end user demands, Journal of Cleaner Production . 